\title{
Copper, zinc, phosphorus and sulfur distribution in thin section of rat brain tissues measured by laser ablation inductively coupled plasma mass spectrometry: possibility for small-size tumor analysis $\dagger$
}

\author{
J. Sabine Becker, ${ }^{a}{ }^{a}$ Miroslav V. Zoriy, ${ }^{a}$ Markus Dehnhardt, ${ }^{b}$ Carola Pickhardt ${ }^{a}$ and \\ Karl Zilles ${ }^{b}$ \\ ${ }^{a}$ Central Division of Analytical Chemistry, Research Centre Juelich, D-52425 Juelich, Germany. \\ E-mail: s.becker@fz-juelich.de \\ ${ }^{\boldsymbol{b}}$ Institute of Medicine, Research Centre Juelich, D-52425 Juelich, Germany
}

Received 8th April 2005, Accepted 20th June 2005

First published as an Advance Article on the web 18th July 2005

\begin{abstract}
A microanalytical method using laser ablation inductively coupled plasma mass spectrometry (LA-ICP-MS) was developed to measure element distribution in rat brain tissues for the detection of a small-size tumor. The stereotaxically guided tumor was implanted by injecting $5 \mu 1$ of $10^{3}$ F98 cells into the right Caudatus putamen of a male F344 Fisher rat brain hemisphere. The second non-treated rat brain hemisphere is used as control tissue. Tumor investigation of adjacent slices is carried out by LA-ICP-MS and, in addition, autoradiographically with a tritiated ligand $\left({ }^{3} \mathrm{H}-\mathrm{PK} 11195\right)$ of the peripheral benzodiazepine-receptor, which is not expressed in the brain under normal, physiological conditions but during tumor development. Ion intensities of ${ }^{63} \mathrm{Cu}^{+},{ }^{64} \mathrm{Zn}^{+},{ }^{31} \mathrm{P}^{+}$and ${ }^{32} \mathrm{~S}^{+}$in the rat brain section (thickness: $20 \mu \mathrm{m}$; analyzed area $12 \mathrm{~mm}$ by $6 \mathrm{~mm}$ ) containing the local tumor and control area were measured by scanning with a focused laser beam at wavelength $213 \mathrm{~nm}$, diameter of laser crater $50 \mu \mathrm{m}$ and laser power density $3 \cdot 10^{9} \mathrm{~W} \mathrm{~cm} \mathrm{~cm}^{-2}$, in a cooled laser ablation chamber coupled to a double-focusing sector field ICP-MS. The quantitative determination of element distribution in a thin slice of the rat brain tissue was carried out using matrix-matched laboratory standards. The mass spectrometric analysis yielded an inhomogeneous distribution for $\mathrm{Cu}, \mathrm{Zn}, \mathrm{S}$ and $\mathrm{P}$ in the analyzed rat brain sections. For $\mathrm{Cu}$ and $\mathrm{Zn}$ a deficiency in and around the tumor region in comparison with the control brain tissue of the second hemisphere was found. The detection limits for distribution analysis of $\mathrm{Zn}$ and $\mathrm{Cu}$ measured by LA-ICP-MS are in the $\mathrm{ng}^{-1}$ range. The capability and the limits of LA-ICP-MS will be studied for the imaging of element distribution in thin cross sections of brain tissues in order to create a new diagnostic method for the borders of small-size tumors.
\end{abstract}

\section{Introduction}

Metal ions, phosphorus and sulfur play important roles in biological systems as essential components or toxic impurities for the regulation of intracellular functions, for example, by signal transduction or the interaction of proteins with DNA. A deficit of essential elements (e.g., $\mathrm{Fe}, \mathrm{Cu}, \mathrm{Se}, \mathrm{Zn})$ in tissue can result in deficiency diseases, but too high concentrations of these metals can also cause toxic reactions. ${ }^{1}$

Phosphorus is very important in many physiological processes, such as glycolysis and nucleic acid turnover. Furthermore, it is essential for the generation of adenosine triphosphate (ATP) from adenosine diphosphate (ADP) and inorganic phosphorus $\left(\mathrm{P}_{\mathrm{i}}\right)$ in the oxidative phosphorylation process from the respiratory chain.

Tumors have a very high energy demand and high rate of glucolysis, therefore phosphorus was chosen as one non-metal element to image by micro-local analytical technique.

Sulfur is contained primarily in proteins such as those of redox-systems like the tripeptide glutathione, and in the aminoacid cysteine, which is growth delimiting (rats are capable of synthesizing cysteine, but it is not sufficient under growth conditions and conditions of high energy turnover) and thus essential in the rat but not in humans, and was therefore chosen.

$\dagger$ Presented at the 2005 European Winter Conference on Plasma Spectrochemistry, January 30-February 3, 2005, Budapest, Hungary.
Metals, phosphorus and sulfur are mostly heterogeneously distributed in biological or medical tissues, therefore imaging (or mapping) analysis of element distribution in small areas of biological tissues is a challenging task in analytical chemistry and of increasing interest in different areas of biological research. Powerful analytical techniques with a good lateral resolution and detection limit are necessary for imaging studies in tissues. Histochemical staining techniques have often been used for the visualization of element distributions in tissue but they possess no multielement capability. Other surface analytical techniques, such as scanning electron microscopy with energy dispersive X-ray analysis (SEM-EDX), ${ }^{2}$ proton-induced X-ray emission (PIXE) ${ }^{3}$ or autoradiography ${ }^{4}$ are generally not sensitive enough for trace analysis. Several working groups used matrix-assisted laser desorption/ionization mass spectrometry (MALDI-MS) for imaging organic compounds and biological tissues. ${ }^{5-7}$ Using secondary ion mass spectrometry (SIMS) it is possible to produce ion images of the distribution of chemical elements in tissue with a lateral resolution in the low $\mu \mathrm{m}$ and sub- $\mu \mathrm{m}$ range, but quantification is difficult due to inherent matrix effects up to 6 orders of magnitude. ${ }^{8-10}$ Therefore, laser ablation inductively coupled plasma mass spectrometry (LA-ICP-MS) is a new powerful and sensitive surface analytical technique for biological matrices $^{11-15}$ with significantly lower matrix effects and an easy quantification procedure. If no suitable standard reference material is available several strategies have been developed 
for quantification purposes in LA-ICP-MS using a preparation of matrix-matched laboratory standards or by solution-based calibration. Due to these advantages, LA-ICP-MS, which is mostly used as a trace analytical technique for the bulk analysis of solid inorganic matrices and partly for isotope ratio measurements, ${ }^{16-19}$ will also be applied to an increasing extent for element distribution analysis (including analysis of trace elements) in biological samples and medical tissues (e.g., in tree barks, ${ }^{20}$ green leaves, ${ }^{21}$ fish $^{22}$ or liver tissue ${ }^{13}$ ). In addition, LAICP-MS was applied as a microlocal analytical method for the determination of $\mathrm{P}, \mathrm{S}, \mathrm{Si}$ and metal concentrations (Al, $\mathrm{Zn}, \mathrm{Cu}$ und $\mathrm{Fe}$ ) in well-separated protein spots after two-dimensional gel electrophoresis in brain samples of patients with Alzheimer's disease and in control brains. ${ }^{15}$ The lateral resolution of distribution analysis by LA-ICP-MS is in the $\mu \mathrm{m}$ range, but in comparison with SIMS large areas of tissue can be ablated. For example, Kidness et al. ${ }^{13}$ developed an analytical procedure using LA-ICP-MS with a cooled laser ablation chamber (see ref. 11) for the quantitative determination of two-dimensional element distribution (mapping) of $\mathrm{Cu}$ and $\mathrm{Zn}$ in sections of the liver tissue of sheep. A homogeneous certified reference material (CRM LGC 7112, pig liver) was applied to quantify the analytical data.

For the analysis of biological tissues by LA-ICP-MS, a cooled laser ablation chamber (using two Peltier elements behind the target holder made of aluminium) was constructed in our laboratory enabling a significant improvement of stability of the ion currents, thus leading to better precision and higher accuracy of the analytical data as recently demonstrated for uranium isotope ratio measurements on the surface of biological tissue. ${ }^{23}$ Using this experimental arrangement, imaging of $\mathrm{Cu}$ and $\mathrm{Zn}$ in $20 \mu \mathrm{m}$ thin sections of human brain tissue (hippocampus) was described in a previous paper. ${ }^{14}$ The mass spectrometric analysis yielded a layered structure for $\mathrm{P}, \mathrm{S}, \mathrm{Cu}$ and $\mathrm{Zn}$ in thin brain sections of the hippocampus. Th and $\mathrm{U}$ were found to be more homogeneously distributed at a low concentration level with detection limits in the low $\mathrm{ng} \mathrm{g}^{-1}$ range. For quantification purposes, besides the application of synthetic laboratory standards, a new calibration strategy of on-line solution-based calibration using micronebulization (the micronebulizer was inserted directly into the laser ablation chamber) was introduced. ${ }^{14}$

The aim of this work is to apply LA-ICP-MS as a microanalytical technique for the quantitative determination of $\mathrm{Zn}$, $\mathrm{Cu}, \mathrm{P}$ and $\mathrm{S}$ distribution in thin sections of rat brain tissues implanted with a tumor in comparison with a control tissue. The results on selected sections of rat brain tissue measured by LA-ICP-MS will provide information on the lateral element distribution of essential elements in brain samples and could lead to a new diagnostic method for small brain tumors.

\section{Experimental}

\section{Instrumentation and measurement procedure}

LA-ICP-MS. A double-focusing sector field ICP-MS (ICPSFMS, ELEMENT, Thermo Electron Corporation, Bremen, Germany) coupled to the Ablascop laser ablation system (Bioptic, Berlin) was used to produce images of $\mathrm{Cu}, \mathrm{Zn}, \mathrm{P}$ and $S$ in thin rat brain tissue sections (thickness: $20 \mu \mathrm{m}$ ). The experimental arrangement of the cooled laser ablation chamber is shown in Fig. 1. Laser ablation of biological tissue was performed using a frequency-quintupled Nd:YAG laser (wavelength: $213 \mathrm{~nm}$, repetition frequency: $20 \mathrm{~Hz}$, spot diameter: $50 \mu \mathrm{m}$; laser power density: $3 \cdot 10^{9} \mathrm{~W} \mathrm{~cm}^{-2}$ ). The ablated material was transported by argon as a carrier gas into the inductively coupled plasma (ICP). The ions formed in the ICP were extracted in the sector-field mass spectrometer and separated according to their mass-to-charge ratios. In order to avoid isobaric interferences all measurements were performed

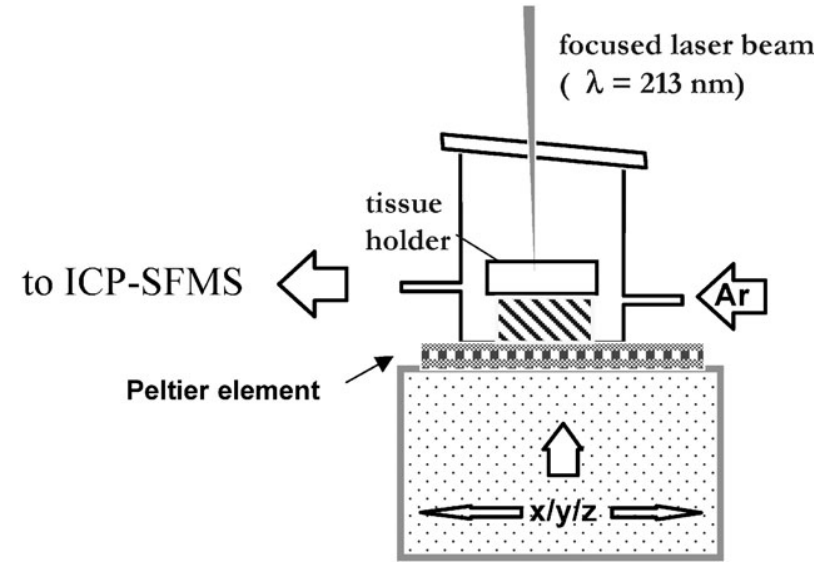

Fig. 1 Experimental setup of LA-ICP-MS using cooled laser ablation chamber.

at medium mass resolution, $m / \Delta m$, of 4400 . The ICP torch was shielded with a grounded platinum electrode (GuardElectro$\mathrm{de}^{\mathrm{TM}}$, Thermo Electron Corporation). For calibration a single gas flow solution-based procedure was applied using an ultrasonic nebulizer (USN, CETAC Technologies Inc., Omaha, Nebraska, USA) described elsewhere. ${ }^{15}$ Using this experimental arrangement, simultaneous optimization of the nebulizer gas flow rate for the USN and the carrier gas flow rate for the transport of laser-ablated material in ICP is possible. The optimization of experimental parameters in LA-ICP-MS using an ultrasonic nebulizer, which is coupled on-line to the cooled laser ablation chamber and the optimized parameter, is summarized in Table $1 .{ }^{14}$ The background intensity of the analytes of interest was determined directly in a blank brain tissue (preparation of homogeneous synthetic laboratory standard is described below) by LA-ICP-MS.

Calibration procedure in LA-ICP-MS. For the calibration of analytical data, matrix-matched laboratory standards with well-defined element concentrations were prepared. Standard solutions containing the elements of interest $(\mathrm{Cu}, \mathrm{Zn}, \mathrm{P}$ and $\mathrm{S})$ in defined concentrations were produced. Three slices of the same brain tissue (each about $0.65 \mathrm{~g}$ ) were spiked with selected standard solutions. The final concentrations in brain tissue were $10,5,1 \mu \mathrm{g} \mathrm{g}^{-1}$ of $\mathrm{Cu}, \mathrm{Zn}, \mathrm{P}$ and $\mathrm{S}$. The fourth slice was not spiked and was used for blank correction. All spiked brain samples were carefully homogenized and centrifuged for $5 \mathrm{~min}$. After that, samples were frozen at a temperature of $-50{ }^{\circ} \mathrm{C}$. Frozen matrix-matched synthetic laboratory standards of brain tissues were cut into sections $20 \mu \mathrm{m}$ in thickness and placed onto the glass substrate. Calibration curves were produced by measuring the ion intensities of analytes. The matrixmatched synthetic laboratory standards can be used for calibrating a multitude of LA-ICP-MS measurements.

Samples and sample preparation. Slices of rat brains frozen in $-50{ }^{\circ} \mathrm{C}$ isopentane were obtained in a Leica 3010 cryostat at $-20{ }^{\circ} \mathrm{C}$ and $20 \mu \mathrm{m}$ thickness. In brief, coronal sections were separated into four sets for staining. The first of the consecutive slices was subjected to ${ }^{3} \mathrm{H}-\mathrm{CPFPX}$-autoradiography, the second to cresyl violet staining, the third to ${ }^{3} \mathrm{H}-\mathrm{PK} 11195$ autoradiography, and the fourth was investigated by use of LA-ICP-MS. In addition, immunohistochemistry (IHC) and in situ hybridization (ISH) can be applied until the complete tumor had been macroscopically sectioned (indicated by fast methylene blue stain and light microscopy) (see Fig. 2).

Autoradiography. Autoradiography was performed by the following slice preparation method, as described earlier by 
ICP-MS (ELEMENT, Thermo Electron, Bremen)

\begin{tabular}{|c|c|c|c|}
\hline Rf power/W & 1200 & Laser ablation system & Ablascope \\
\hline Cooling gas flow rate $/ 1 \mathrm{~min}^{-1}$ & 18 & Wavelength/nm & 213 \\
\hline Auxiliary gas flow rate $/ 1 \mathrm{~min}^{-1}$ & 1 & Laser power density $/ \mathrm{W} \mathrm{cm}{ }^{-2}$ & $3 \cdot 10^{9}$ \\
\hline Carrier gas flow rate $/ 1 \mathrm{~min}^{-1}$ & 1.2 & Laser energy per pulse $/ \mathrm{mJ}$ & 6 \\
\hline Mass resolution $(m / \Delta m)$ & 4400 & Repetition frequency $/ \mathrm{Hz}$ & 20 \\
\hline Number of runs (pass) & $150(1)$ & Spot diameter $/ \mu \mathrm{m}$ & 50 \\
\hline Analysis time per line $(5 \mathrm{~mm}) / \mathrm{min}$ & 12 & Temperature of tissue $/{ }^{\circ} \mathrm{C}$ & -10 \\
\hline
\end{tabular}

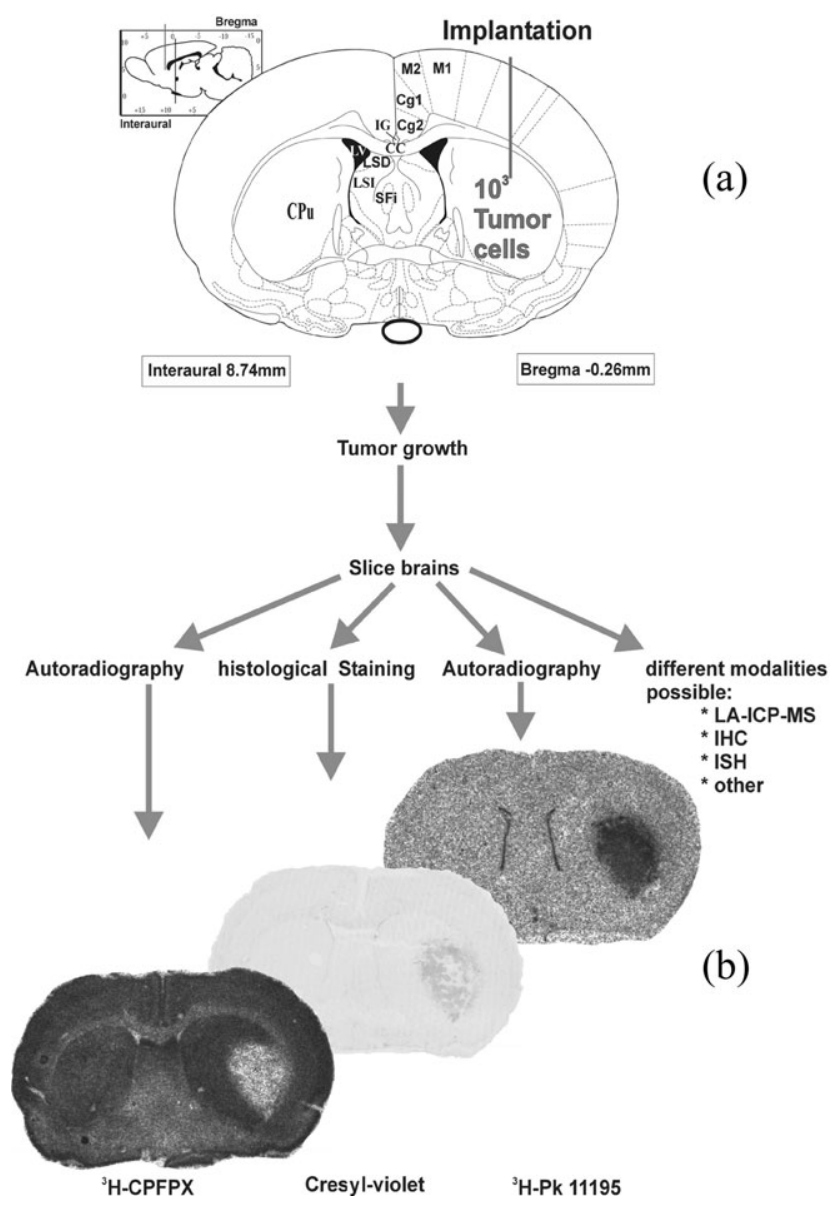

Fig. 2 Stereotaxically guided tumor implantation by injection of F98 tumor cells into the right caudate putamen. Explanation of tumor implantation side (a) and experimental procedure (b). (a) $10^{3}$ F98 tumor cells were implanted into the right caudate putamen by stereotaxic guidance. Following 18 days of tumor growth, brains were removed, frozen in $-50{ }^{\circ} \mathrm{C}$ isopentyl alcohol and cut at $-20{ }^{\circ} \mathrm{C}$ into $20 \mu \mathrm{m}$ thick slices. Insertion: schematic drawing of a sagittal view. Atlas-based coordinates for implantation are $-2.5,2,0,-5.0 \mathrm{~mm}$ with respect to Bregma (interaural-line). (b) Slices were subjected to four different protocols, either autoradiography (each consecutive slice 1 and 3), histological cresyl violet staining (consecutive slice 2), and to immuno-histochemistry, in situ hybridization or LA-ICP-MS (slice 4). Receptor-autoradiography was done for ${ }^{3} \mathrm{H}-\mathrm{CPFPX}$, a specific $\mathrm{A}_{1}$ adenosine receptor ligand $\left(\mathrm{A}_{1} \mathrm{AR},\left(K_{\mathrm{D}}=4 \mathrm{nM}\right)\right.$, of ${ }^{3} \mathrm{H}-\mathrm{Pk} 11195$, a specific ligand for the peripheral benzodiazepine receptor $\left(K_{\mathrm{D}}=0.1 \mathrm{nM}\right)$ and tumor marker in the brain. Abbreviations: $\mathrm{CC}$ - corpus callosum $\mathrm{LV}$ - lateral ventricle, $\mathrm{Cpu}$ - caudate putamen, LSD/LSI-lateral septal nucleus, dorsal/intermediate part, $\mathrm{df}$ - dorsal fornix, $\mathrm{f}$ - fornix, M1-primary motor cortex, M2 - secondary motor cortex, Cg1-cingulate cortex area $1, \mathrm{Cg} 2$ - cingulate cortex area $2, \mathrm{IG}$ - indusium griseum, Sfi-septofimbrial nucleus, IHC-immunohistochemistry, ISH-in situ hybridization.

Bauer et al. ${ }^{24}$ Rat brain sections were dried in a stream of cold air for 1 hour and either stored in evacuated plastic bags at $-80{ }^{\circ} \mathrm{C}$ for later processing or directly subjected to autoradiographic procedures. Slices of tissue were exposed to a specific ligand for the peripheral benzodiazepine receptor, ${ }^{3} \mathrm{H}-$ PK11195 ([ ${ }^{3} \mathrm{H}$-(1-(2-chlorophenyl)- $N$-methyl- $N$-(1-methylpropyl)-3-isoquinoline-carboxamide)], at $100 \mathrm{pM}$ ), which is only expressed in the brain under patho-physiological conditions of tumor development. Non-specific binding was determined with slices on which the tritiated ligand competed against an excess of unlabeled probe, cold PK11195. The reactive zone is indicated by arrows in both pictures. Alternatively, slices were autoradiographed with ${ }^{3} \mathrm{H}$-CPFPX, $\left({ }^{3} \mathrm{H}-8\right.$-cyclopentyl-3-(-3fluoropropyl)-1-propylxanthin), a specific marker for $\mathrm{A}_{1}$ adenosine receptor $\left(\mathrm{A}_{1} \mathrm{AR}\right)$ at $4 \mathrm{nM}$, which has been shown to be a promising marker for invasive zones of tumors in rat studies as well as in human high-grade glioma patients described by Bauer et al. ${ }^{25}$

Quantification of analytical data was done by employing a Bas reader and AIDA software (Raytest, Freiburg, Germany). Plates were normalized to an appropriate ${ }^{3} \mathrm{H}$-tissue standard (Amersham, Freiburg, Germany).

Tumor cells and in vitro procedures. F 98 cells were obtained from ATCC (American type culture collection, Manassas, VA, USA). Cells were cultured in ATCC complete growth medium: Dulbecco's modified Eagle's medium with $4 \mathrm{mM}$ L-glutamine, $1.5 \mathrm{~g} \mathrm{~L}^{-1}$ sodium bicarbonate and $4.5 \mathrm{~g} \mathrm{~L}^{-1}$ glucose $(90 \%)$, $10 \%$ fetal bovine serum (FBS), temperature: $37.0{ }^{\circ} \mathrm{C}$, atmosphere: air, $95 \%$; carbon dioxide $\left(\mathrm{CO}_{2}\right), 5 \%$. For subcultivation, cells were briefly rinsed with $0.05 \%(\mathrm{w} / \mathrm{v})$ trypsin -0.53 $\mathrm{mM}$ EDTA solution to remove all traces of serum containing trypsin inhibitor, $2.0-3.0 \mathrm{ml}$ of trypsin-EDTA solution was added and cells were observed under an inverted microscope until the cell layer was dispersed (usually within 5-15 min). Following this, $6.0-8.0 \mathrm{ml}$ of complete growth medium was added and cells were aspirated by gently pipetting. A subcultivation ratio of $1: 6$ to $1: 10$ was followed as recommended. The medium was changed every $2-3$ days. Cells were kept in culture to approximately $80 \%$ confluence and passaged. Only passages between passage 20 and 30 were used for the experimental procedures. A schematic explanation of tumor implantation procedures and tumor implantation sites ${ }^{26}$ is shown in Fig. 2.

\section{Results}

\section{Imaging of $\mathrm{Cu}$ and $\mathrm{Zn}$ in thin sections of rat brain tissue}

In Fig. 3 the two-dimensional concentration profile of copper in a $20 \mu \mathrm{m}$-thick section of brain tissue analyzed by LA-ICPMS is shown. For quantification of analytical data three prepared matrix-matched laboratory standards were applied. ${ }^{14}$ Calibration curves on laboratory standards were measured using LA-ICP-MS with a correlation coefficient better than 0.9 . The analytical data are corrected in respect to background intensity measured on "blank" sample.

The element distribution for copper, zinc, sulfur and phosphorus in a rat brain slice are presented in Figs. 3, 4, 5(a) and 5(b), respectively. All elements investigated are inhomogenously distributed in brain tissue. In the image of $\mathrm{Cu}$ (Fig. 3) the 


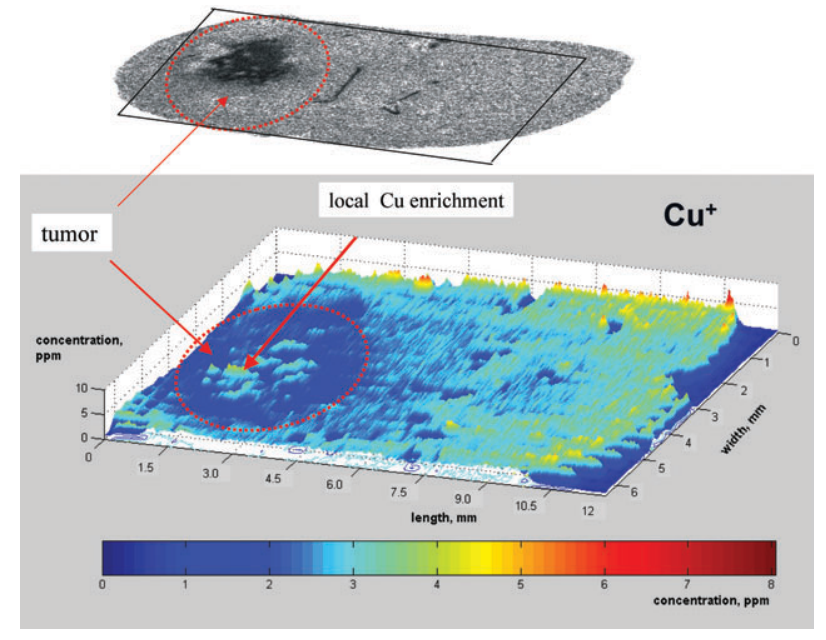

Fig. 3 Image of copper in $20-\mu \mathrm{m}$ thin section of rat brain tissue measured by LA-ICP-MS in comparison to autoradiograph (on top).

area of tumor is clearly seen in the left hemisphere of rat brain tissue. As a result of scanning a rat brain section it was found that the shape of the implanted tumor in the $\mathrm{Cu}$ image agrees with the image of histochemically stained thin section (see inset figure on top). Furthermore, in comparison with the surrounding tissue the area of tumor is marked by a copper deficiency. In contrast to the $\mathrm{Cu}$ distribution in the left hemisphere of rat brain (in Figs. 3-5 the control tissue is presented opposite on the right) a nearly homogeneous copper distribution in the healthy tissue was observed. The $\mathrm{Cu}$ concentration was found, in the tumor area, to be about $1.8 \mu \mathrm{g} \mathrm{g}^{-1}$ : this is about a half of the $\mathrm{Cu}$ concentration of control tissue. In the middle of the tumor region local $\mathrm{Cu}$ enrichments can be observed. The average $\mathrm{Cu}$ concentration in the control brain tissue was found to be $3.8 \mu \mathrm{g} \mathrm{g}^{-1}$. Especially in the histologically cresyl violet stained thin brain section (see Fig. 2) which indicates the shape of the small tumor, similar inhomogeneities are clearly seen. These inhomogeneities - demonstrated in Fig. 3-correspond to an enrichment of $\mathrm{Cu}$ with a concentration in the 3-4.6 $\mu \mathrm{g}$ $\mathrm{g}^{-1}$ range. Furthermore, the $\mathrm{Cu}$ image of this section of rat brain measured by LA-ICP-MS also seems to be correlated with the autoradiograph as demonstrated in Fig. 2.

Fig. 4 represents the distribution of zinc in the analyzed rat brain tissue. The $\mathrm{Zn}$ image is very similar to those of copper as demonstrated by LA-ICP-MS. This is valid with respect to the shape of the tumor and also relating to the inhomogeneities present inside the tumor tissue, although the local enrichments of $\mathrm{Zn}$ in the middle of the tumor area have a lower concentration in comparison with $\mathrm{Cu}$ (about 2.5-3.1 $\mu \mathrm{g} \mathrm{g}^{-1}$ ). The $\mathrm{Zn}$ concentration inside the tumor tissue was about $2.2 \mu \mathrm{g} \mathrm{g}^{-1}$. The detection limits for $\mathrm{Cu}$ and $\mathrm{Zn}$ determination in thin brain tissues using LA-ICP-MS were determined as $0.8 \mu \mathrm{g} \mathrm{g}^{-1}$.

In contrast to the structure of the essential elements $\mathrm{Zn}$ and $\mathrm{Cu}$, which show an elemental deficiency (Figs. 3 and 4), uranium was also detected in rat brain tissue. In analogy to findings on the hippocampus, uranium appears with a relatively homogeneous profile in the cross section of the rat brain tissue by microlocal measurements using LA-ICP-MS. The detection limits of the microanalytical technique for $U$ determination in thin sections of rat brain tissues using LA-ICP-MS were determined as $10 \mathrm{ng} \mathrm{g}^{-1} .14$

Also for sulfur (see Fig. 5(a)) a deficit was found in the tumor region. The sulfur concentration measured by LA-ICPMS is significantly higher in the control brain with local enrichments in comparison with the tumor area ( $\sim 200 \mathrm{ppb})$. In the phosphorus image (Fig. 5(b)) the rat brain structures of the Caudate Putamen and the superficial lying white matter tracts, as well as lateral ventricles, can be clearly recognized. Local enrichments of phosphorus up to $6-7 \mu \mathrm{g} \mathrm{g}^{-1}$ were observed in the tumor area.

\section{Discussion}

Tumor size versus distribution pattern of metal ions. The dimensions of single cell bodies are about $25 \mu \mathrm{m}$ diameter. Tumors are composed according to the nature of high cellular densities.

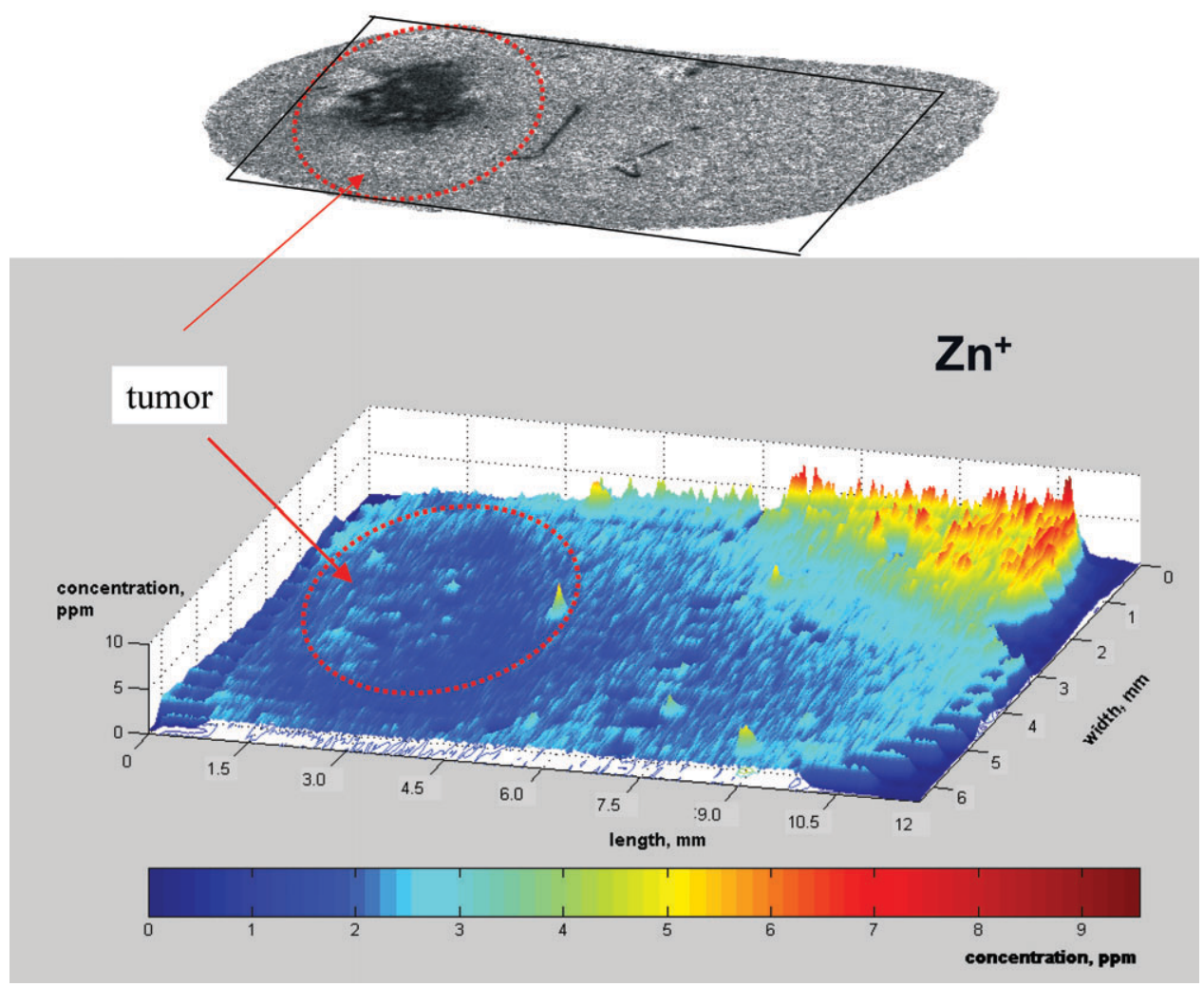

Fig. 4 Zinc distribution in 20- $\mu \mathrm{m}$ thin section of rat brain tissue measured by LA-ICP-MS in comparison to autoradiograph (on top). 

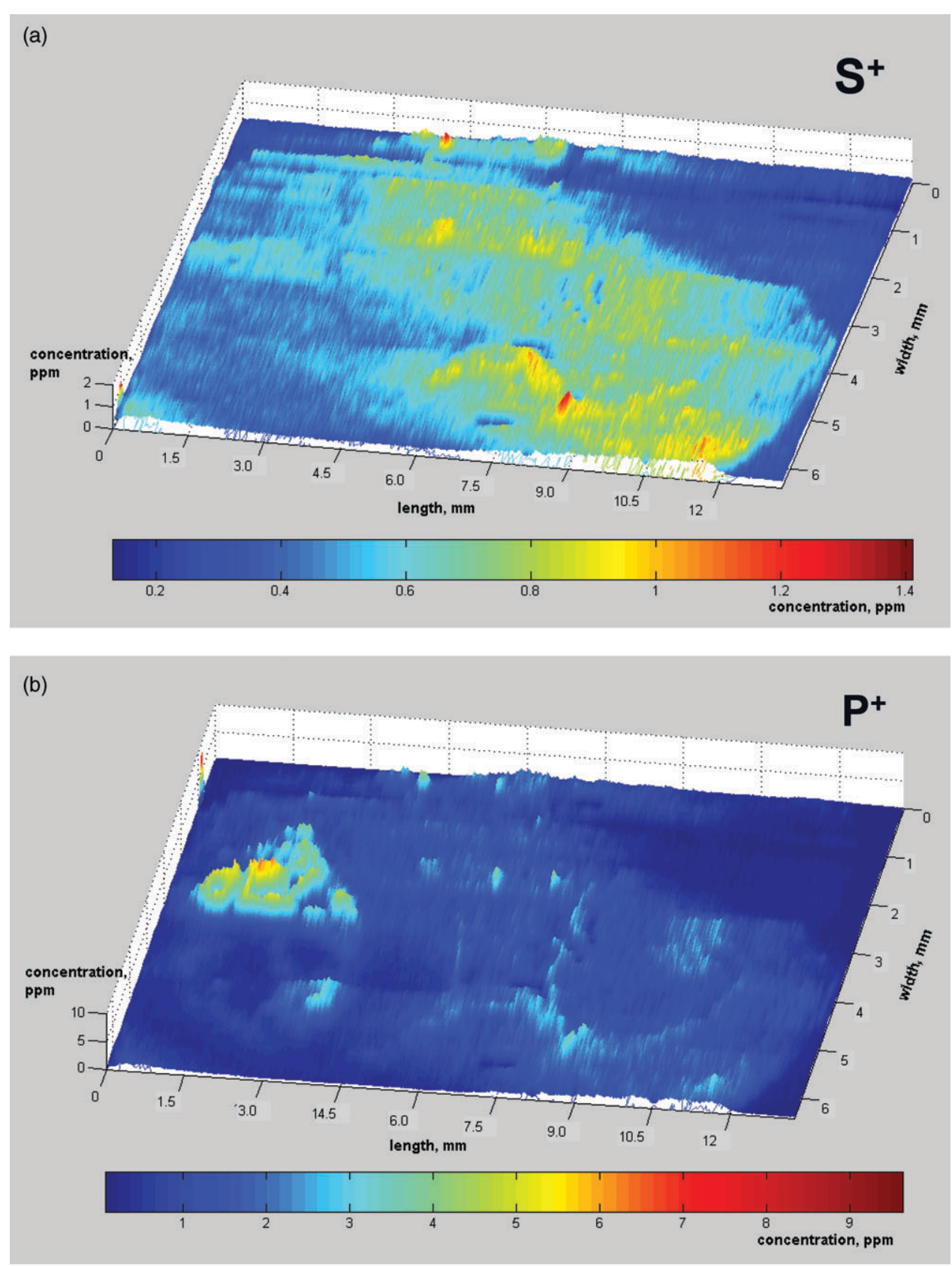

Fig. 5 (a) Sulfur distribution in 20- $\mu \mathrm{m}$ thin section of rat brain tissue measured by LA-ICP-MS. (b) Image of phosphorus in 20- $\mu \mathrm{m}$ thin section of rat brain tissue measured by LA-ICP-MS.

In experimental tumor models an allograft transplantation of tumor cells is the basis for studying pathological processes in the ongoing invasiveness and malignancy of brain tumors.

Despite different xenograft models employing various human tumor cell lines, the autologous chemically induced derived F98 tumor cell line, established in the late 1960s, is employed in one of nine currently well established tumor models in the rat as described by Benda et al. ${ }^{27}$ and Barth. ${ }^{28}$ Due to the highly invasive nature and fast growing properties, following implantation of only $1000 \mathrm{~F} 98$ tumor cells the tumor reaches an estimated size of $1.5 \mathrm{~mm}^{3}$ within 10 days and of about $3-4 \mathrm{~mm}^{3}$ within 18 days.

Furthermore, in the primary reactive zone around the tumor an edema is observable due to dying cells, reactive astrocytes and matrix metalloproteases secreted by the tumor cells as described by Ohnishni et al. ${ }^{29}$

Because the maximum diffusion distance for oxygen is about $3 \mathrm{~mm}$ in tissue, cells in the center of tumors often undergo necrosis, where cells simply die because of insufficient energy and oxygen support. On the other hand, as soon as a tumor obtains a blood supply by sprouting of blood vessels and neovascularization, which is one of the characteristic features of high grade gliomas, exponential growth behavior can be observed as described by Kleihues et al. ${ }^{30}$ These processes all have to be kept in mind regarding an inhomogeneous distribution of metal ions across a tumor area.

The loss of cellular entities or brain nuclei because of toxic damage can be assessed according to their ion-pattern distribution and these pattern distributions might be of great prognostic value for clearly estimating tumor borders during neurosurgery and the discovery of metastases for the neuropathologist.

The rat brain tumor model employed for this preliminary study is ideal, since F98 tumor cells of an astrocytic tumor cell line are characterized very well and are broadly distributed in experimental oncology laboratories.

Furthermore, the apparent lack of A1 adenosine receptors and the upregulation of peripheral benzodiazepine receptors during in vivo tumor growth, as evidenced by the appropriate tritiated ligands, ${ }^{3} \mathrm{H}-\mathrm{CPFPX}$ and ${ }^{3} \mathrm{H}-\mathrm{Pk} 11195$, respectively, 
provides an extremely useful target for further characterization of tumor tissue by LA-ICP-MS.

Future systematic studies on thin sections of rat brain tissues in comparison with control brain tissues will focus on screening of different types of tumors in order to explain fundamental processes such as the influence of essential and toxic elements on the development of tumors. In order to identify smaller structures a significant improvement in lateral resolution is necessary, down to the sub- $\mu \mathrm{m}$ range in LA-ICP-MS for microlocal analysis in biological tissues, combined with the possibility of quantitative element determination. At present we are developing such new analytical LA-ICP-MS techniques for interesting future applications in the life sciences and also microelectronics.

\section{Conclusion}

A microlocal analytical technique was applied for two-dimensional screening of $\mathrm{Cu}, \mathrm{Zn}, \mathrm{P}$ and $\mathrm{S}$ in a cryo-section of rat brain tissue using LA-ICP-MS for detecting small-size tumors. Sufficient lateral resolution and elemental sensitivity, as well as a relatively short analysis time, proves that LA-ICP-MS with a cooled laser ablation chamber (applied at medium mass resolution) is a powerful technique for elemental distribution analysis on thin biological tissues. In order to perform a reliable quantification of measured ion intensities, synthetic laboratory standards of similar matrix composition doped with analytes of defined concentrations were used. As a result of scanning $20-\mu \mathrm{m}$ brain tissue in an implanted tumor of rat brain tissue a deficit of $\mathrm{Cu}$ and $\mathrm{Zn}$ with local enrichment was detected. Because the tumor area shows a different element distribution compared with the control tissue the analytical procedure developed for elemental screening using LA-ICPMS is suitable for detecting very small tumors, for example, in brain tissues. A possible application of this technique could be in better determination of tumor cell- and edema distribution in pathological tissue areas in operative resections, as well as probing and proofing correlations of element distribution throughout body-tissues in any organ in correlation with environmental element distribution for better risk assessment.

Obviously, LA-ICP-MS is a destructive analytical technique, but this microlocal analytical method could be of interest as a new tumor diagnostic. Systematic studies of element distribution in small growing tumors will help physicians to better understand the chemical basis of various brain diseases.

\section{Acknowledgements}

This work was supported by the Deutsche Forschungsgemeinschaft, Bonn, Germany (SFB 575). The first author is very grateful to H.-J. Dietze (Juelich, Germany) for valuable discussions.

\section{References}

1 S. J. Lippard and J. M. Berg, Bioorganische Chemie, Spektrum, Akademischer Verlag, Heidelberg, 1994.

2 V. Mizuriha, H. Hasegawa and M. Notoya, Acta Histochem. Cytochem., 1997, 30, 3125.

3 J. Mesjasz-Przybylowicz and W. J. Przybylowicz, Nucl. Instr. Meth. B, 2002, 189, 470

4 A. Takeda, H. Tamano, S. Enomoto and N. Oku, Cancer Res. 2001, 61, 5065

5 P. J. Todd, T. G. Schaaf, P. Chaurand and R. M. Caprioli, J. Mass Spectrom., 2001, 36, 355.

6 P. Chaurand, M. Sanders, R. A. Jensen and R. M. Caprioli, Am. J. Pathol., 2004, 165, 1057.

7 S. L. Luxembourg, T. H. Mize, L. A. McDonnell and R. M. A. Heeren, Anal. Chem., 2004, 76, 5339.

8 G. H. Morrison, I. Gay and S. Chandra, Scanning Microsc., Suppl., 1994, 8, 359.

9 S. Chandra, Appl. Surf. Sci., 2003, 203-204, 679.

10 D. Touboul, F. Halgand, A. Brunelle, R. Kersting, E. Tallarek, B. Hagenhoff and O. Laprevote, Anal. Chem., 2004, 76, 1550

11 J. Feldmann, A. Kindness and P. Ek, J. Anal. At. Spectrom., 2002, $\mathbf{1 7}, 813$.

12 A. M. Ghazi, J. C. Wataha, N. L. O'Dell, B. B. Singh, R. Simmons and S. Shuttleworth, J. Anal. At. Spectrom., 2002, 17, 1295.

13 A. Kindness, N. Sekaran and J. Feldmann, Clin. Chem., 2003, 49, 1916.

14 J. S. Becker, M. V. Zoriy, C. Pickhardt, N. Palomero-Gallagher and K. Zilles, Anal. Chem., 2005, 77, 3208.

15 J. S. Becker, M. Zoriy, J. S. Becker, C. Pickhardt and M. Przybylsky, J. Anal. At. Spectrom., 2004, 19, 149.

16 C. Pickhardt, H.-J. Dietze and J.S. Becker, Int. J. Mass Spectrom, $2005,242,273$.

17 J. S. Becker and H.-J. Dietze, Int. J. Mass Spectrom., 2003, 228, 127.

18 S. F. Boulyga, D. Desideri, M. A. Meli, C. Testa and J. S. Becker, Int. J. Mass Spectrom., 2003, 226, 329.

19 C. Pickhardt, I. B. Brenner, J. S. Becker and H.-J. Dietze, Fresenius' J. Anal. Chem., 2000, 368, 79.

20 E. Hoffmann, C. Lüdke and H. Stephanowitz, Fresenius' J. Anal. Chem., 1996, 355, 900.

21 E. Hoffmann, C. Lüdke, J. Scole, H. Stephanowitz, E. Ullrich and D. Colditz, Fresenius' J. Anal. Chem., 2000, 367, 579.

22 P. Ek, Winter Conference on Plasma Spectrochemistry, 1999.

23 M. Zoriy, M. Kayser, C. Pickhardt and J. S. Becker, Int. J. Mass Spectrom., 2005, 242, 297.

24 A. Bauer, M. H. Holschbach, M. Cremer, S. Weber, C. Boy, N. J. Shah, R. A. Olsson, H. Halling, H. H. Coenen and K. Zilles, J. Nucl. Med., 2003, 44, 1682.

25 A. Bauer, K. J. Langen, H. J. Bidmon, M. H. Holschbach, S. Weber, R. A. Olsson, H. H. Coenen and K. Zilles, J. Nucl. Med., $2005,46,450$.

26 G. Paxinos and C. Watson, The Rat Brain in Stereotaxic Coordinates, Academic Press, Sydney, 1986.

27 P. Benda, J. Lightbody, G. Sato, L. Levine and W. Sweet, Science, 1968, 161, 370

28 R. F. Barth, J. Neuro-Oncology, 1998, 36, 91-102.

29 T. Onishni, P. B. Sher, J. B. Posner and W. R. Shapiro, J. NeuroOncology, 1991, 10, 13.

30 P. Kleihues, D. N. Louis, B. W. Scheithauer, L. B. Rorke, G. Reifenberger, P. C. Burger and W. K. Cavenee, J. Neuropathol. Exp. Neurol., 2002, 61, 215. 